\title{
Study of rock structure properties during combined stopping and development headings
}

\author{
Vladimir Golik ${ }^{1,2}$, Galina Stas $^{3}$, Vladimir Morkun ${ }^{4, *}$, Natalia Morkun $^{4}$, and Irina Gaponenko ${ }^{4}$ \\ ${ }^{1}$ North Caucasus State Technological University, 44 Nikolaev Str., Vladikavkaz, 362021, Russia \\ ${ }^{2}$ Geophysical Institute, Vladikavkaz Scientific Center, 93a Markov Str., Vladikavkaz, 362002, Russia \\ ${ }^{3}$ Tula State University, 92 Lenin Ave., Tula, 300012, Russia \\ ${ }^{4}$ Kryvyi Rih National University, 11 Vitalii Matusevych Str., Kryvyi Rih, 50027, Ukraine
}

\begin{abstract}
The purpose of this study is to establish the mechanism of interaction between stresses and strains and their quantitative values at the intersection of stopping and development headings to optimize methods for controlling the behaviour of the rock massif. The research complex includes priority methods with experimental confirmation of the calculated parameters by geophysical studies, including stress calculation by a sensor system and surveying levelling to measure deformations using support frames. The properties of the massif and the role of faults and macro-cracks in the development of a field of a complex structure are systematized. A method for studying the stresses and deformations of rocks at the intersection of stopping and development headings is given. The patterns of the rock massif behaviour at the point of intersection are established. The article provides quantitative values of changes in the physical and mechanical properties and stability of rocks at the point of intersection. Massif was differentiated according to the magnitude of the effective stresses in different phases of the intersection. Stresses for specific conditions were calculated with the determination of the reliability of the mining site. The patterns of change in stresses and strains in time are noted.
\end{abstract}

\section{Introduction}

The operated deposit is an underground structure with an internal arrangement and a system of elements. The construction parameters are calculated by methods of structural mechanics, which includes the principles and methods for calculating the strength, stiffness, and stability of structures. Structural mechanics is a tool for calculations related to the strength, stiffness, and stability of both individual elements and the structure as a whole [1-3].

The safety of underground structures is assessed by comparing the actual value of the risk with its value, established based on a situation analysis. For the sake of objectivity, comparable construction geotechnologies should be comparable in the maximum number of features: ore reserves, dip angle, ore and gangue rock characteristics, plant production capacity, and cost of operations. When comparing technology, the risk indicator can be determined by one main parameter, for example, by the bearing capacity of a structure from rocks exposed by mining.

The control effect on the strength of the system consists in the use of parameters at which the strength of the bearing rock structures is ensured by the residual strength of the rocks and the stresses of the lateral active rocks pressure, which can be increased by hardening the rocks.
Controlling the strength of the rock structures consists of the implementation of the residual bearing capacity of the rocks by limiting the size of the spans of the workings. Within geomechanically balanced areas, underground and construction geotechnologies minimized in terms of labour and materials costs can be applied.

The greatest danger to underground objects is the critical deformation of the rock mass in the case of insufficient strength of natural or artificially created supporting structures - pillars, which depend on the spans of exposure of the rock roof between the supports. The processes in the rock masses are stochastic, the initial information for solving the technical and economic problems in the mining industry is probabilistic, so the evaluation of the behaviour of the massif and its impact on underground objects is a serious problem, the relevance of which increases with the scale of the expansion of mining in the deep of Earth.

To increase the safety of natural-technogenic structures, the safety margin of the pillars is sought to be increased. This is accompanied by an increase in ore losses in the security pillars and an increase in the cost of materials for the construction of artificial supports.

The underground structural analysis employs general laws of mechanics and proportions that take into account the physical and mechanical properties of the rock mass, the conditions of the interaction of elements, parts, and structure base. According to the measurement results, a

\footnotetext{
* Corresponding author: morkunv@gmail.com
} 
design scheme for the structure and a mathematical model in the form of a system of recurrent equations are formed. The advantages of structural mechanics in the mining industry include the ability to solve dynamic problems because the underground structure is a system operating under the influence of variable dynamic loads and force fields [4-6]. A prerequisite for the safe and efficient underground exploitation of mineral deposits is accounting for and using the properties of the ore-bearing rock massifs. The quality of the extracted raw materials and the number of expenses for managing rock structures depend on the completeness of property accounting; therefore, the dynamic of stresses and strains in the process of mining ores is the goal of field studies, including geophysical and surveying methods.

The safety and efficiency of mine development are ensured by preventing critical stresses in the elements of the ore-rock-ground system, arising from the interaction of man-made (caverns, explosion seismic, vibration, etc.) and natural (tectonics, gravity, seismicity) factors of field development. The increase in the depth of mining and the increase in mineral extraction enhances the scale of the impact on the ore-bearing massifs, the stability of which is the result of the interaction of the emerging force fields. The most dangerous conditions are created when the ore bed is intersected with workings.

The experience gained in controlling the properties of an array can be reduced to the following:

- in underground mining, fractured rocks have residual strength and are capable of creating supporting structures; - the use of rock structures during mining is an effective way to improve the performance of underground and construction geotechnologies;

- the reliability of the control of rock masses state enclosing mountain objects is increased by using measures to adjust the sizes of structural blocks by technological means;

- the use of rock structures creates an economic effect, reducing losses entirely and improving the quality of mineral resources extracted, and reducing the cost of labour and materials for the control of rock pressure. The rocks of different ages in the geological structure of rock deposits are involved. The leading role in the structure and ore content of the deposit belongs to faults. Near the tectonic faults, the fracturing increases, reaching a maximum in the operating faults and near them.

The ratio of the dimensions of the permissible span by stability and the span of the collapsed arch becomes a priority safety criterion, especially when mining rocks over a large area, for example, with the leaching of metals from ore deposits. The most dangerous phenomena in the form of loss of stability or dynamic forms of rock pressure occur when the ore is excavated in areas of articulating structural disturbances composed of strong but fractured and weakened rocks. The behaviour of rock masses during development depends on the interaction of natural and technical factors. Natural factors include, first of all, the stresses acting in it at different periods. Research in this area is aimed at predicting the development of rock pressure at the intersection of workings to make timely management decisions and sustainable development.

\section{Research methods}

The study of rock mass management technologies uses a systematic approach that includes a set of studies: analytical studies based on literature data, field studies (surveying, stress and strain measurements), laboratory tests (modelling of materials) and theoretical (finite element method, thermodynamic, energy, etc.) [7-11].

Considering the uniqueness of each deposit, the priority is given by methods with experimental confirmation of calculated parameters. Applied technologies are divided into various types based on the use of the destroyed rocks residual bearing capacity. The range of studies in this area includes: "Structural analysis", "Structural dynamic", "Analytical and numerical methods for structural analysis", "Stability calculation".

In underground construction geological and surveying tools are used, including [12-20]:

- stress measurement in lining by strain gauges;

- deformation measurement in lining by levelling (fig. 1).

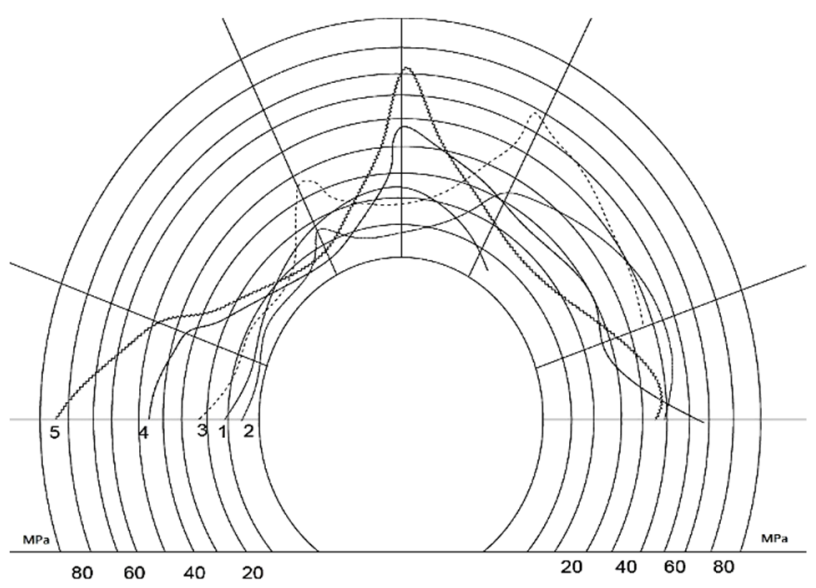

Fig. 1. Stress $\sigma_{\mathrm{x}}$ distribution diagram of the frame lining for measurements No. 1-5.

The dependences of stresses on time obtained by the authors are described mathematically in the course of analytical studies. The state of the rock masses during mining is monitored by a complex method, including analysis of analogues, calculations using theories of elasticity, plasticity, and transverse deformation, experimental studies using acoustic and electromagnetic emission, seismic sounding, ultrasonic and shock wave monitoring. The basis for successful field development is the combination of the tasks of ensuring geomechanical safety by introducing system monitoring and diagnosing the condition of the rock mass.

System monitoring of the geomechanical state of the ore-bearing massif and underground structures provides continuous monitoring and technical diagnostics. The primary monitoring is the separation of the geotechnical system in the control of individual objects with the synthesis of results to predict the effectiveness of the functioning of the production cycle of the system as a whole. It is a complex of theoretical concepts and a fleet of technical means for their implementation in practice and is carried out using sound metric, surveying, and optical instruments, string tensometers, deep and ground 
benchmarks, electrical circuits, visual and indirect methods for changing the salinity of mine water. Establishing a relationship between natural and technological factors makes it possible to clarify the standards of discovered, prepared, and ready for excavation ore reserves under geomechanical conditions.

\section{Results}

The development of rock deposits increases stress to critical levels with a deterioration in the quality of subsoil use, which increases the urgency of the problem of geodynamic processes control. The maximum stresses develop during the stage-by-stage mining of deposits by chamber-pillar systems in the places of equipment of temporary and permanent pillars and in areas of changing the power of ore bodies.

The level of critical stress here exceeds the average values by 2-3 times. Reducing the level of stress to a safe value is ensured by engineering activities with advanced unloading of massifs. The optimum ratio of ore deflection parameters and stress levels is ensured by using technology optimization techniques based on account of seismic blasting effects on the array and surface objects.

A significant role in the behaviour of ore-massif in underground mining of complex structural deposits, for example, Vostok (Kazakhstan), is played by faults and macro fractures forming fracture and splitting zones of rocks with seams filled with friction clay or quartzcarbonate veins [21 - 28].

The physical and mechanical properties of the rocks obtained (by the authors) by the laboratory and field studies at the Vostok deposit (Northern Kazakhstan) are presented in Table 1.

Table 1. Physical and mechanical properties of rocks.

\begin{tabular}{|c|c|c|c|c|c|}
\hline $\begin{array}{c}\text { Charac- } \\
\text { teristic } \\
\text { of rocks }\end{array}$ & $\begin{array}{c}\text { Densi- } \\
\text { ty } \boldsymbol{\rho}, \\
\mathbf{g} / \mathbf{c m}^{\mathbf{3}}\end{array}$ & $\begin{array}{c}\text { Compres- } \\
\text { sive } \\
\text { strength } \\
\boldsymbol{\sigma}_{\boldsymbol{c}}, \mathbf{M P a}\end{array}$ & $\begin{array}{c}\text { Tensile } \\
\text { strength } \\
\boldsymbol{\sigma} \boldsymbol{T}, \mathbf{M P a}\end{array}$ & $\begin{array}{c}\text { Com- } \\
\text { pressi- } \\
\text { onal ve- } \\
\text { locity } \\
\boldsymbol{V}_{\boldsymbol{c}}, \mathbf{m} / \mathbf{s}\end{array}$ & $\begin{array}{c}\text { Acoustic } \\
\text { impe- } \\
\text { dance, } \\
\mathbf{1 0} \mathbf{g} / \mathbf{s} \\
\mathbf{\text { cm }}\end{array}$ \\
\hline $\begin{array}{c}\text { Andesitic } \\
\text { porphy- } \\
\text { rites }\end{array}$ & 2.80 & 105.9 & 8.4 & 4753 & 13.4 \\
\hline $\begin{array}{c}\text { Quartz } \\
\text { porphyry } \\
\text { modified }\end{array}$ & 2.87 & 77.8 & 3.8 & 3452 & 9.9 \\
\hline $\begin{array}{c}\text { Quartz } \\
\text { porphyry } \\
\text { sheared }\end{array}$ & 2.71 & 26.4 & 3.4 & 2612 & 7.09 \\
\hline $\begin{array}{c}\text { Facette } \\
\text { conglo- } \\
\text { merate }\end{array}$ & 2.73 & 77.0 & 14.5 & - & - \\
\hline $\begin{array}{c}\text { Minerali- } \\
\text { zed silt- } \\
\text { stone-ar- } \\
\text { gillite }\end{array}$ & 2.70 & 62.0 & 15.0 & - & - \\
\hline
\end{tabular}

The dynamic of stress changes closer to the ore body was investigated by the strain gauge method. The deformation of the lining was calculated by measuring the distances between the bench mounted on 27 metal frames on a $13 \mathrm{~m}$ long section. In the other development, 9 metal frames were installed. The strain gauge station was placed on 5 metal frames in the second development. On each frame 9, measuring points were installed, including individual sensors glued on three planes. Stresses and strains were recorded once a month. According to the measured deformations $\varepsilon_{0}, \varepsilon_{\mathrm{f} 1}, \varepsilon_{\mathrm{f} 2}$, the main deformations were calculated:

$$
\varepsilon_{1,2}=\frac{\varepsilon_{f_{2}}+\varepsilon_{f_{1}}}{2} \pm \frac{\sqrt{2}}{2} \sqrt{\left(\varepsilon_{f_{2}}-\varepsilon_{f_{1}}\right)^{2}+\left(\varepsilon_{0}-\varepsilon_{f_{1}}\right)},
$$

And angle $\varphi$ between $\xi_{0}$ and $\xi_{1}$

$$
\operatorname{tg} \phi_{0}=\frac{\varepsilon_{f_{1}}-\varepsilon_{f_{2}}}{2 \varepsilon_{0}-\varepsilon_{f_{1}}-\varepsilon_{f_{2}}} \cdot \operatorname{tg} \phi_{1}
$$

The principal stresses, according to Hooke's law:

$$
\begin{aligned}
& \sigma_{1}=\frac{E}{1-\mu^{2}}\left(\varepsilon_{1}+v \varepsilon_{2}\right), \\
& \sigma_{2}=\frac{E}{1-\mu^{2}}\left(\varepsilon_{2}+v \varepsilon_{1}\right),
\end{aligned}
$$

where $E$ - elasticity modulus; $v$ - Poisson's ratio.

Normal stresses $\sigma_{\mathrm{z}}-$ vertical and $\sigma_{\mathrm{x}}$ - horizontal:

$$
\begin{aligned}
& \sigma_{\mathrm{z}}=\sigma_{1} \sin \alpha-\sigma_{2} \sin \alpha, \\
& \sigma_{\mathrm{x}}=\sigma_{1} \sin \alpha-\sigma_{2} \sin \alpha .
\end{aligned}
$$

The looseness of the massif was determined based on the measurement results. The stress dynamic was measured by sensors of the well walls displacement drilled in the study area [29-32]. It is established that the well walls displacement is a function both of the load intensity and the time of its action (fig. 2).

According to the propagation of deformations, the massif is differentiated into phases:

- in the initial phase of deformation the lining increased from 2 to $16 \mathrm{~mm}$;

- when cutting the ore body from the hanging side, the deformation of the lining increased to $19 \mathrm{~mm}$;

- in the development phase of stopping the lining deformation developed until damage.

With the progress of excavation, the average deformations for 1, 2 and 3 months were: 43, 119, 128 $\mathrm{mm}$ correspondingly. The maximum deformations of the lining are noted in frames located close to the clearing face and in the area of the fault. So, after 6 months, the deformations in the upper arch of frame No. 4 were 233 $\mathrm{mm}$, the width of the lining at a distance of $0.5 \mathrm{~m}$ from the rocks increased by $55 \mathrm{~mm}$. Frame number I9 failed because the center of its upper arch was lowered by 432 $\mathrm{mm}$, and the width of the locks increased by $312 \mathrm{~mm}$.

The load on the lining of advance workings is connected with the phase of stopping correlatively. As long as the ore body behaves as a beam pinched in the sides, rock pressure is distributed evenly. After cutting the segments from the hanging side, the load on the lining elements from stopping increases (Table 2).

Displacements in the fracture zone (sensor No. 10) are caused by a strong disturbance of the fracture zone rocks with the deterioration of their physical and mechanical properties, which sharply reduces the stability of rocks in this zone. It has been established that pillars between cross 
drift equally experience higher deformations than the rock masses even at equidistance from the stope influence (fig. 3).
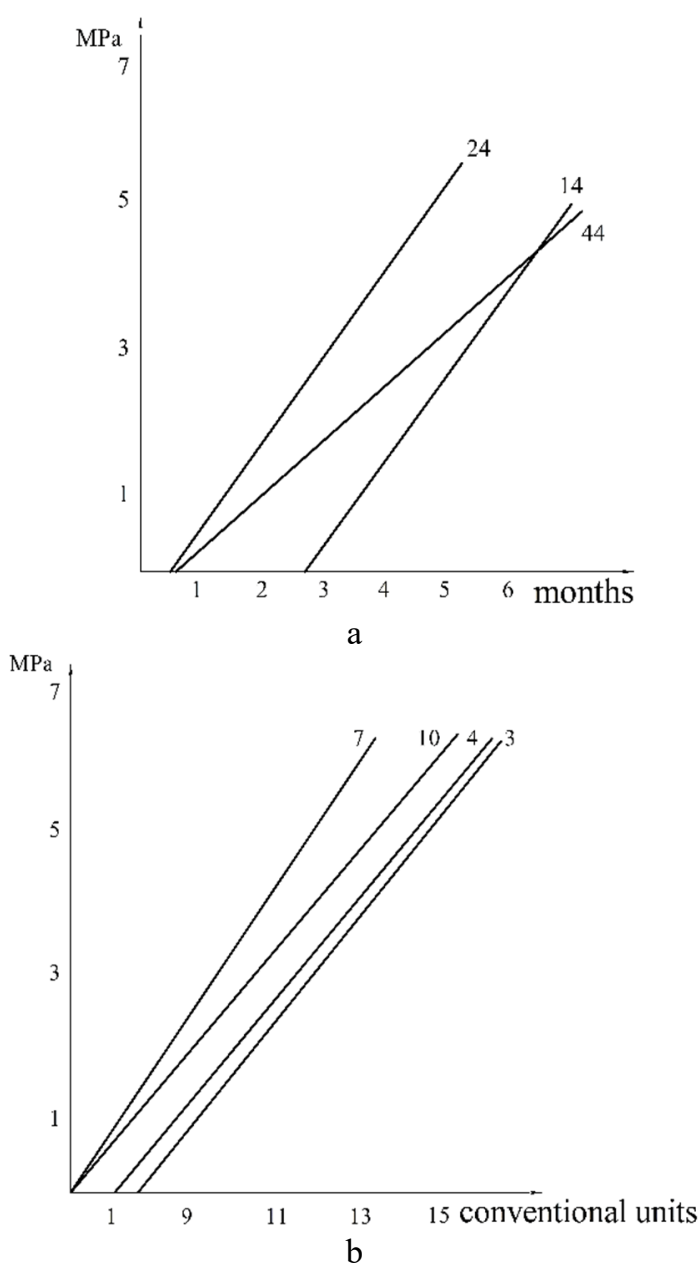

Fig. 2. Sensors indications: $\mathrm{a}$ - pressure, $\mathrm{b}$ - displacement.

Table 2. Results of stress and strain measurements of the sensors.

\begin{tabular}{|c|c|c|c|c|c|c|c|}
\hline \multirow{2}{*}{$\begin{array}{c}\text { Time } t, \\
\text { months }\end{array}$} & \multicolumn{4}{|c|}{ Deformations $d, \mathrm{~mm}$} & \multicolumn{3}{c|}{ Stresses $\sigma, \mathrm{MPa}$} \\
\cline { 2 - 8 } & 4 & \multicolumn{3}{|c|}{ Sensor numbers } & \multicolumn{3}{c|}{ Sensor numbers } \\
\cline { 2 - 8 } & 4 & 3 & 7 & 24 & 44 & 11 \\
\hline 1 & 0.9 & 0.15 & 0.24 & 0.09 & - & - & - \\
\hline 2 & 3.6 & 0.55 & 0,21 & 0.22 & 2.3 & 0.12 & 0.04 \\
\hline 3 & - & 2.2 & 0.26 & 0.24 & 9.7 & 2.35 & 0.85 \\
\hline 4 & - & & 0.50 & 0.26 & 7.65 & 5,1 & 2.65 \\
\hline 5 & - & & 0.90 & 0.62 & & 6.35 & 3.6 \\
\hline 6 & - & & 1.00 & 0.8 & & - & 3.7 \\
\hline
\end{tabular}

Three sections of operating stresses characterize the massif. A slight increase in stress characterizes the initial section. With the approach of the sewage treatment front and the increase subsurface mining area, the ore massif is experiencing an increasing load.

The ratio of rock load above the exploited space and in the stress concentration zone or the pillar presents the information about the massif geodynamics. During the actual mining over the area of length $L$ and width $I$ there is a load $Q$ caused by the mass of overlying rocks $(\gamma \mathrm{H})$ :

$$
Q=L_{1} \gamma H
$$

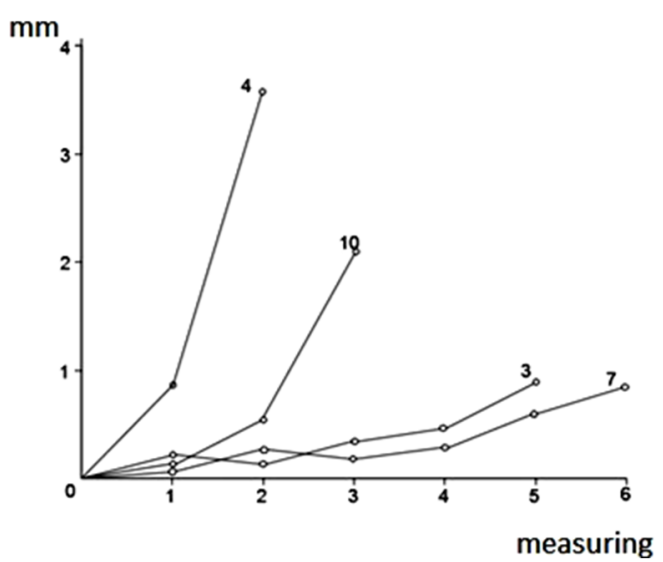

Fig. 3. Well walls displacement in time for sensors No 3, 4, 7, 10.

The magnitude $\gamma \mathrm{H}$, in this case, is $98 \mathrm{MPa}$. If we allow that the mining effect extends to the same length 1 , then the load is:

$$
Q=Q_{1}+Q_{2}
$$

where $Q_{1}$ is the overlying caved rock load, $Q_{2}$ is the load caused by technology.

The load growth in the area of stress concentration in specific conditions is $15-20 \%$ of the gravity component and $39 \mathrm{MPa}$ that is less than the compressive strength of rocks - 54-75 MPa.

The monitoring of the rock mass state by the displacement sensors 3, 7 and pressure sensors shows a slight increase in strain and stress during the first three months of actual mining. Only after three months, the influence of cleaning works is seen. Rock mass stresses increase slower than in the ore. At the end of the actual mining, the stresses and strain in the massif stabilize.

When combining stopping and development headings, their allowable sizes depend on the roof rock behaviour. If structural blocks of rocks are shifted into the developed space, the roof takes the form of a vault. In this case, adding waste rocks worsens ore dilution and losses of metals in the ore dressing, that is why the aim is to save flat roof choosing the work options at which the rocks in the lower layer wedge and hold rock load inside the vault of natural balance (fig. 4).

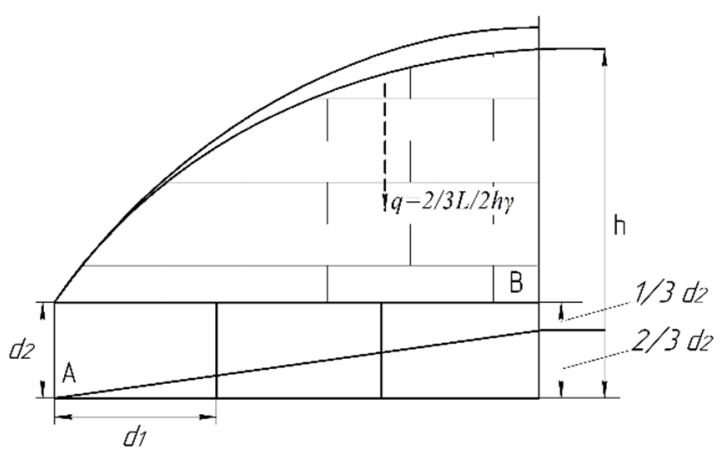

Fig. 4. The condition for the formation of a flat roof: $h$-is the height of the arch of equilibrium; $L$ - is the span width; $d_{1}-$ is the length of elementary structure; $d_{2}-$ is the height of structural units; $\gamma$-is the volume weight of rocks; $q$-is the 
moment of force, A and B - are the edges of the arch of equilibrium.

Vetrov-Golik model describes this condition:

$$
L_{\max }=2 d_{2} \sqrt{\frac{10 R_{\text {com }}}{\kappa_{2} \gamma d_{1}}}
$$

where $L_{\max }$ - the maximum span of the flat roof; $d_{1}$ - the horizontal size of structural blocks, $\mathrm{m} ; d_{2}-$ the vertical size of structural blocks, $\mathrm{m} ; \gamma$ - volume weight of rocks; $K_{2}$ - safety factor.

If the roof is composed of rocks, deformations in which do not exceed the plastic limit, the allowable span of the flat roof is determined from the equations:

$q=\frac{L_{0} h_{0}}{3} ; h_{0}=\frac{L_{0}}{2 V_{0}} ; q=\frac{L_{0}}{2 V_{0}} ; M_{q}=\frac{L_{0} \gamma}{18 V_{0}} ; T=\frac{10 R_{c o m}}{R_{c}} \frac{1}{2} d_{o c} ;$ $M_{T}=T \frac{5}{2} d_{o c}=\frac{10 R_{\mathrm{com}}^{o} \cdot 5 d_{o c}}{18 K_{2}} ; R_{c o m}=R_{c o m}^{\prime}=R_{c o m}^{n}$.

The width of the flat span can be increased, fastening the structural rock blocks by anchors, concrete, etc.:

$q_{H}=\frac{L_{3} b \gamma}{2} ; M_{q}=\frac{L_{3}^{2} b \gamma}{8} ; T=\frac{10 R_{c o m}}{K_{2}} \cdot \frac{2 d n_{2}}{3} ;$

$M_{T}=\frac{10 R_{c o m} \cdot 10 d^{2} n_{2}}{18 K_{2}} ; L_{3}=298 d n_{2} \sqrt{\frac{10 R_{c o m}}{K_{2} \gamma_{6}}}$.

The efficiency of using rock structures in the operation of underground structures is achieved by improving the quality of mined ores and the safety conditions of workers [15-18]. The crushing of distinct rock blocks is a critical component of optimizing the technology for extinguishing the developed space, which makes it possible to develop deposits with an environmental and economic effect while ensuring the safety of mining operations.

In underground mining of rock ore deposits, the phenomenon is realized by constructing the boundaries of the area of dangerous displacements in the rock mass using geophysical research methods. Geophysical monitoring of field development processes allows us to assess the state of the system and the stress-strain state of the rocks, which allows us to assess the stability of the massif under various conditions of void formation.

The proposed approach can be used to detail working projects for managing the state of ore-bearing massifs of rock deposits of complex structure.

\section{Conclusions}

In the process of intensive intervention by mining operations, the ore-bearing massif the structural units of rocks are destroyed and come into contact with each other, often with the creation of jammed systems.

Under certain conditions, emerging structures are used to control the geomechanics of a given section of the earth's crust. The adequate nature of this phenomenon, which can be observed during ore production, allows predicting the behaviour of rock masses with sufficient detail to control the ore-bearing mass, which allows adjusting the development parameters to obtain the economic effect of improving the quality of mined ores and reducing the risk for workers. The efficiency of using rock structures consists of saving labour and materials for controlling the state of rock masses during underground work.

In underground mining of ore deposits, the dynamic of stresses and strains at the intersection of stopping and development headings can be predicted with sufficient detail to control the ore-displacing massif, which makes it possible to adjust the development parameters with the economic effect of improving the quality of mined ores and reducing the risk for workers.

The novelty of the proposed method for predicting the dynamics of rock pressure is the use of mechanostructural properties of discrete structural rocks, in contrast to most methods based on the mechanics of a continuous medium, which brings the calculation results closer to the actual position of the massif.

\section{References}

1. S.N. Krivoshapko, I.A. Mamieva, Analytical surfaces in the architecture of buildings, structures and products (Librocom, Moscow, 2012).

2. N.M. Yakupov, Mechanics: problem - idea practice. Constr. Mech. Eng. Structures 3, 24-37 (2010)

3. V.D. Potapov, A.I. Fimkin, A.R. Pepanyan. Experimental verification of a model of a non-locally elastic foundation. Eng. Mech. Structures 5, 63-68 (2015)

4. V. Golik, V. Komashchenko, V. Morkun, V. Zaalishvili, Enhancement of lost ore. Metall. Mining Ind. 7(4), 325-329 (2015)

5. B. Dold, L. Weibel, Biogeometallurgical pre-mining characterization of the mining process. Envir. Sci. Pollut. Research 20(11), 7777-7786 (2013)

6. A. Khani, A. Baghbanan, S. Norouzi, H. Hashemolhosseini, Effects of fracture rock mass. Int. J. Rock Mech. Mining Sci. 60, 345-352 (2013)

7. Yu.V. Dmitrak, V.M. Logacheva, A.A. Podkolzin, Geophysical forecasting of disturbance and watering of the rock mass. Mining Inf. Anal. Bull. 11, 35-36 (2006)

8. Y.J. Ping, C.W. Zhong, Y.D. Sen, Y.J. Qiang, Numerical determination of strength and deformability of fractured rock mass by FEM modelling. Comp. Geotech. 64, 20-31 (2015)

9. M. Shabanimashcool, C.C. Li, Analytical approaches for studying the stability of laminated roof strata. Int. J. Rock Mech. Mining Sci. 79, 99-108 (2015)

10. V.A. Eremenko, V.N. Lushnikov, M.P. Sandy, D.A. Milkin, E.A. Milshin, V.S. Kshanovsky, Choosing and justifying the technology of carrying out and methods of fixing mine workings in unstable mountains rocks in the deep horizons of the Kholbinsky mine. Gornyi Zhurnal 7, 78-84 (2013)

11. A.D. Kuranov, D.V. Sidorov, Evaluation of the tense state of the interstrate track pillars at the mines of 
OJSC Apatit. News of Tula State Univ. Earth Sciences 1, 308-312 (2011)

12. A.G. Protosenya, A.D. Kuranov, Method of forecasting the stress-strain state of a mountain massif with the combined development of the Koashvinskoe deposit. Gornyi Zhurnal 1, 67-71 (2015)

13. V.I. Lyashenko, Development of geomechanical monitoring of the properties and state of the rock mass during underground mining of complex structures. Marksheydersky Bulletin 1, 35-43 (2016)

14. Yu.V. Dmitrak, E.N. Kamnev, JSC "Leading design and survey and research institute of industrial technology" - a path of 65 years long. Gornyi Zhurnal 3, 6-12 (2016)

15. M.D. Molev, S.A. Maslennikov, I.A. Zanina, N.I. Stuzhenko, Forecasting the state of technosphere safety (ISOiP DGTU, 2015)

16. M.V.Rylnikova, E.A. Emelianenko, N.A. Angelov, Formation of a technogenic massif from enrichment tailings in a waste space with given structural parameters. Gorny inf.-anal. bulletin 1, 115 (2013)

17. V. Golik, V. Komashchenko, V. Morkun, O. Burdzieva, Metal deposits combined development experience. Metall. Mining Ind. 7(6), 591-594 (2015)

18. V. Golik, V. Komashchenko, V. Morkun, Z. Khasheva, The effectiveness of combining the stages of ore fields development. Metall. Mining Ind. 7(5), 401-405 (2015)

19. I. Kotov, O. Suvorov, O. Serdiuk, Development of methods for structural and logical model unification of metaknowledge for ontologies evolution managing of intelligent systems. Eastern-European J. Enterp. Techn. 2(4-98), 38-47 (2019)

20. S. Pysmennyi, D. Brovko, N. Shwager, D. Paraniuk, O. Serdiuk, Development of complex-structure ore deposits by means of chamber systems under conditions of the Kryvyi Rih iron ore field. EasternEuropean J. Enterp. Techn. 5(1-95), 33-45 (2018)

21. A. Kupin, D. Kuznetsov, I. Muzyka, O. Suvorov, V. Dvornikov, The concept of a modular cyberphysical system for the early diagnosis of energy equipment. Eastern-European J. Enterp. Techn. 4(2-94), 71-79 (2018)

22. A. Olovyannyy, Bokovoy raspor i tektonicheskiye napryazheniya $\mathrm{v}$ massive gornykh porod. Gornyi Zhurnal 4, 25-31 (2016)

23. D. O'Sullivan, A. Newman, Extraction and backfill scheduling in a complex underground mine. Interfaces 44(2), 204-221 (2014)

24. W. Wang, S. Huang, X. Wu, Q. Ma, Calculation and management for mining loss and dilution under 3D visualization technical condition. J. Soft. Eng. Appl. 4(5), 329-334 (2011)

25. H. Wang, Y. He, C. Duan, Y. Zhao, Y. Tao, C. Ye, Development of mineral processing engineering education in China University of Mining and Technology. Adv. Comp. Sci. Eng., 77-83 (2012)

26. M. Iofis, E. Fedorov, E. Yesina, N. Miletenko, Razvitiye geomekhaniki dlya resheniya problem sokhraneniya zemnykh nedr. Gornyy Zhurnal 11, 6774 (2017)

27. A. Bahri Najafi, G.R. Saeedi, M.A. Ebrahimi Farsangi, Risk analysis and prediction of out-of-seam dilution in longwall mining. Int. J. Rock Mech. Mining Sci. 70, 115-122 (2014)

28. A. Benardos, I. Athanasiadis, N. Katsoulakos, Modern earth sheltered constructions: a paradigm of green engineering. Tunn. Undergr. Space Techn. 41, 46-52 (2014)

29. J. Liu, Y. Han, Y. Li, S. Zhang, Study on mechanism and technology of deep reduction for iron ore leaching, in 26th International Mineral Processing Congress, IMPC 2012: Innovative Processing for Sustainable Growth, New Delhi, India, pp. 23352343

30. G. Granata, K. Takahashi, T. Kato, C. Tokoro, Mechanochemical activation of chalcopyrite: Relationship between activation mechanism and leaching enhancement. Miner. Eng. 131, 280-285 (2018)

31. Y. Ghorbani, J.P. Franzidis, J. Petersen, Heap leaching technology - current State, innovations, and future directions: a review. Min. Proc. Extr. Metall. Rev. 37(2), 73-119 (2016)

32. E. Fan, L. Li, X. Zhang, Y. Bian, Q. Xue, J. Wu, F. $\mathrm{Wu}, \mathrm{R}$. Chen, Selective Recovery of Li and Fe from Spent Lithium-Ion Batteries by an Environmentally Friendly Mechanochemical Approach. ACS Sust. Chem. Eng. 6 (8), 11029-110315 (2018) 